\title{
ANALISIS PERAN LEMBAGA DHARMA DUTA DALAM MEMBANGUN SINERGI DENGAN TIM KOORDINASI DAN INTEGRASI GRAND DESIGN HINDU DHARMA INDONESIA DALAM MENINGKATKAN KUALITAS PENYULUH AGAMA HINDU DI INDONESIA
}

Oleh :

\author{
Made Awanita
}

\begin{abstract}
Grand Design Hindu Dharma Indonesia (GDHDI) is intended as a guide for stakeholders and all Indonesian Hindus since designing the future of Hinduism in Indonesia is basically a process by design in order to survive and to the growth of Indonesian Hindus, both in quantity and quality. The urgent need the Hindus people in the present, one of them is to optimize the role of the Dharma Duta as agents of change to be able to reach people and to do religious guidance effectively and efficiently. Dharma Duta role now has been facilitated by Lembaga Dharma Duta under the auspices of the Parisada Hindu Dharma Indonesia. GDHDI which began to be introduced and defined in Mahasabha X Parisada Hindu Dharma Indonesia would be very good if it is supported by studies that scientifically, especially in relation to the role of the Lembaga Dharma Duta which is also in line with the mission of GDHDI, so it needs to conduct a study of how the Lembaga Dharma Duta ann Coordination and Integration Team GDHDI can work together in carrying grand design road-map.

The study used a qualitative approach using qualitative descriptive method. In this study, the primary data obtained through interviews with informants. Determination of informants using purposive sampling. Methods of data collection used literature study, observation, and interviews.

The results of this research are still needed socialization to the Hindus people in Indonesia related to the work program which is owned by the Lembaga Dharma Duta and GDHDI; still need for strong coordination between the Lembaga Dharma Duta and GDHDI associated with the plan and implementation work aimed at improving the quality of Hindu Religious Counselor in Indonesia; Needs seriousness and focusness of the Lembaga Dharma Duta about many aspects that still needed in improving the quality of Hindu Religious Counselor; and needed programs and strategies appropriate work should be designed jointly by the Lembaga Dharma Duta and GDHDI to improve and maximize the Hindu Religious Counselor qualities throughout Indonesia.
\end{abstract}

Keywords: Synergy, Grand Design Hindu Dharma Indonesia, Lembaga Dharma Duta. 


\section{PENDAHULUAN}

Agama Hindu telah hadir di Indonesia sejak awal sejarah Nusantara dan telah menjadi fondasi kehidupan bermasyarakat dan bernegara di seluruh wilayah Nusantara. Masuknya Hindu di Indonesia melatarbelakangi perkembangan peradaban Nusantara yang ditandai dengan munculnya kerajaan-kerajaan Hindu, seperti: Salakanagara, Tarumanagara, Kutai, Sriwijaya, Mataram, Kanjuruhan, Majapahit dan lainnya.

Kerajaan Majapahit yang telah mampu mempersatukan Nusantara, memberikan inspirasi yang sangat kuat bagi umat Hindu untuk menata kembali tatanan kehidupannya menuju kejayaan Indonesia.

Setelah menikmati kejayaan selama beberapa ratus tahun, peradaban Hindu di Indonesia memasuki masa-masa kelam dengan runtuhnya kerajaan Majapahit yang ditandai dengan candrasangkala hilang sirna kertaning bhumi pada tahun 1400 Saka (1478 M). Hilangnya ketentraman bumi nusantara (Indonesia) seakan menjadi kenyataan dengan kedatangan penjajah yang menancapkan kekuasaannya beberapa tahun kemudian. Penjajahan tersebut berlangsung berabad-abad sampai pada akhirnya bangsa Indonesia memproklamasikan kemerdekaan pada tanggal 17 Agustus 1945.

Kemerdekaan Indonesia tidak serta merta mengembalikan eksistensi Hindu sebagai sebuah agama. Hal ini terbukti dengan dimasukkannya Hindu (Bali) sebagai aliran kepercayaan dalam struktur Kementerian Agama RI yang dibentuk beberapa bulan setelah Republik Indonesia terbentuk. Hal ini memicu kalangan agama di Bali untuk berjuang mengembalikan Hindu kepada jatidirinya sebagai sebuah agama. Perjuangan tersebut menunjukkan hasil dengan dibentuknya Bahagian Urusan Hindu Bali pada tahun 1958. Kelembagaan tersebut mengalami perubahan (peningkatan) menjadi Biro Urusan Hindu Bali pada tahun 1963, kemudian menjadi Direktorat Jenderal Bimbingan Masyarakat Hindu dan Buddha pada tahun 1967 dan menjadi Direktorat Jenderal Bimbingan Masyarakat Hindu pada tahun 2006.

Perkembangan dalam suprastruktur politik (pemerintahan), juga diikuti dengan perkembangan dalam infrastruktur politik (kemasyarakatan) dengan didirikannya sebuah Majelis Agama Hindu yaitu Parisada Dharma Hindu Bali pada 
23 Februari 1959, kemudian diubah menjadi Parisada Hindu Dharma pada tahun 1964 dan pada tahun 1986 berubah menjadi Parisada Hindu Dharma Indonesia.

Kedua institusi tersebut di atas, yaitu Direktorat Jenderal Bimbingan Masyarakat Hindu Kementerian Agama Republik Indonesia dan Parisada Hindu Dharma Indonesia, bersama-sama dengan organisasi kemasyarakatan dan lembaga Hindu lainnya, bahu membahu mewarnai kiprah agama dan umat Hindu Indonesia dalam membangun masyarakat, bangsa, dan negara Republik Indonesia sampai saat ini.

Nilai spriritual Hindu yang universal saat ini banyak digunakan oleh masyarakat baik di Indonesia maupun di dunia sebagai tuntunan kehidupan dalam upaya untuk meningkatkan kesadaran diri.

Mengantisipasi perkembangan lingkungan dan kebutuhan umat di masa yang akan datang, umat Hindu di Indonesia memandang perlu untuk mendesain masa depan dan membuat peta perjalanannya (road map). Adanya desain secara khusus tentang rencana masa depan Hindu Indonesia membuat arah tujuan serta kontribusi umat Hindu di Indonesia dalam kehidupan bermasyarakat, berbangsa, dan bernegara semakin jelas.

Parisada Hindu Dharma Indonesia sebagai majelis tertinggi agama Hindu bersama organisasi kemasyarakatan Hindu serta seluruh pemangku kepentingan (stake holders) di Indonesia memiliki tanggung jawab utama dalam menentukan arah dan bentuk-bentuk kontribusi umat Hindu dalam kehidupan bangsa Indonesia ke depan. Oleh karenanya, dalam forum Pesamuhan Agung Parisada Tahun 2011, Panitia Pesamuhan Agung mengambil inisiatif dan mengusulkan rancangan "Grand Design Hindu Nusantara” yang kemudian disepakati dengan nama “Grand Design Hindu Dharma Indonesia (GDHDI)" sebagai desain utama strategi pembinaan dan pengembangan Hindu di Indonesia.

Rancangan "Grand Design Hindu Dharma Indonesia (GDHDI)" ini disahkan oleh Parisada Hindu Dharma Indonesia sebagai majelis tertinggi agama Hindu Indonesia pada Mahasabha X Parisada di Denpasar, tahun 2011. "Grand Design Hindu Dharma Indonesia" ini dijadikan sebagai acuan arah (visi) dan peta perjalanan umat Hindu Indonesia dalam kurun waktu 50 tahun yang akan datang. 
Perjalanan panjang umat Hindu Indonesia 50 tahun yang akan datang dipetakan menjadi dua tahapan besar, yakni tahapan jangka menengah 25 tahun pertama dan tahapan 25 tahun kedua, yang dilengkapi dengan target-target dan indikator-indikator capaiannya. Rencana 25 tahun pertama dijabarkan ke dalam tahapan 5 tahunan dengan peta perjalanan, tema, program-program kerja serta target-target dan indikator-indikator capaiannya.

Grand Design Hindu Dharma Indonesia dimaksudkan sebagai panduan bagi para pemangku kepentingan dan seluruh umat Hindu Indonesia untuk berjalan ke arah yang sama, sehingga keberadaan serta kontribusinya bagi kemajuan Indonesia dapat lebih nyata di masa yang akan datang. Proses ini menunjukkan bahwa umat Hindu di Indonesia dikelola secara strategik dengan pendekatan manajemen modern. Mengelola umat Hindu dengan manajemen strategik berarti dengan sengaja mendesain masa depan Hindu di Indonesia dalam menghadapi turbulensi perubahan yang demikian pesat. Bila umat Hindu tidak mendesain masa depannya di Indonesia dari sekarang maka orang lain yang akan melakukannya. Umat Hindu dapat bercermin dari masa lalunya di Indonesia. Lima ratus tahun lebih sudah umat Hindu didesain oleh orang lain, 500 tahun lebih sudah umat Hindu mengalami penciutan dan pengkerdilan, dan tidak perlu 500 tahun lagi untuk hilang dari Bumi Nusantara jika kondisi tanpa desain ini terus dibiarkan. Kemajuan bangsa dan peradaban di Indonesia membutuhkan nilai-nilai Hindu yang begitu indah, alamiah, ilmiah, luas, dalam, dan universal.

Mendesain masa depan Hindu di Indonesia pada dasarnya adalah proses yang diskenariokan agar bertahan hidup dan menuju pertumbuhan umat Hindu di Indonesia, baik dalam kuantitas dan kualitas. Agar bertahan hidup maka harus bertumbuh (grow). Menurut teori, cara bertumbuh ada dua, yang pertama adalah grow by accident dan yang kedua adalah grow by design. Grow by accident pada hakikatnya adalah "menuju ke lembah kematian". Sedangkan grow by design berarti dengan sengaja mendesain diri sendiri dengan cara menentukan visi, menetapkan strategi, dan membuat rencana implementasinya. Dalam manajemen strategik, ada empat tahapan utama yang umum diterapkan yaitu Situation Analysis, Strategy Formulation, Strategy Implementation, dan Evaluation \& Control. 
Grand Design Hindu Dharma Indonesia adalah rumusan yang merupakan rencana induk (master plan) pertumbuhan Hindu di Indonesia sebagai hasil dari tahap pertama dan kedua dalam manajemen strategik, yaitu tahap Situation Analysis dan Strategy Formulation. Agar rencana induk ini dapat diimplementasikan maka perlu disosialisasikan kepada seluruh pemangku kepentingan (stake holders) di Indonesia dan juga perlu disiapkan agen-agen perubahan (change agents) yang menjalankannya. Dalam konteks manajemen strategik, dua tahap berikutnya harus dijalankan secara berkesinambungan, yaitu tahap Strategy Implementation dan tahap Evaluation \& Control.

Sosialisasi Grand Design Hindu Dharma Indonesia dilakukan dengan membentuk Tim Koordinasi dan Integrasi Grand Design Hindu Dharma Indonesia yang melibatkan pengurus dan aktivis dari tujuh organisasi Hindu berskala nasional yaitu Parisada Hindu Dharma Indonesia (PHDI), Wanita Hindu Dharma Indonesia (WHDI), Perhimpunan Pemuda Hindu Indonesia (Peradah Indonesia), Kesatuan Mahasiswa Hindu Dharma Indonesia (KMHDI), Pinandita Sanggraha Nusantara (PSN), Prajaniti Hindu Indonesia (Prajaniti), dan Ikatan Cendekiawan Hindu Indonesia (ICHI). Sedangkan penyiapan agen-agen perubahan (change agents) yang menjalankan Grand Design Hindu Dharma Indonesia perlu melibatkan semua pemangku kepentingan, satu di antaranya adalah para Dharma Duta berikut Lembaga Dharma Duta yang mengelolanya.

Visi Grand Design Hindu Dharma Indonesia adalah "Terwujudnya masyarakat Hindu Dharma Indonesia yang sejahtera lahir batin (moksartham jagadhitaya) bersumber pustaka suci Veda dan berdasarkan Pancasila”. Sedangkan Misi dari Grand Design Hindu Dharma Indonesia adalah "Menjaga keutuhan dan pemahaman umat dengan menyebarluaskan nilai-nilai keyakinan dan filsafat (tatwa), etika (susila), dan ritual (acara) Hindu dalam kehidupan modern; Meningkatkan kesadaran masyarakat untuk membangun sumberdaya manusia yang maju dan mandiri berdasarkan Dharma; Menumbuhkembangkan wawasan, solidaritas, dan keharmonisan internal, antar umat beragama, dan antara umat beragama dengan pemerintah". Dalam mencapai visi dan misi tersebut maka pembinaan umat adalah salah satu kuncinya. 
Kebutuhan mendesak umat pada saat kini, salah satunya adalah optimalisasi peran dari para Dharma Duta sebagai agen-agen perubahan untuk dapat menjangkau masyarakat dan melakukan pembinaan-pembinaan yang intensif serta efektif dan efisien. Pembinaan kepada umat Hindu khususnya yang jarang terjangkau kegiatan pembinaan sangat dibutuhkan oleh umat. Faktor masih banyaknya umat Hindu yang minim tentang pengetahuan agamanya menjadi salah satu penyebab beralihnya keyakinan umat dari agama Hindu ke agama lain. Jika kita data, upaya yang dilakukan oleh misionaris, media, maupun upaya politik agama lain berpotensi membuat cukup banyak umat mengalihkan keyakinannya dari Hindu ke agama lain. Di sinilah salah satu yang membuat peran Dharma Duta menjadi penting pada saat ini.

Dharma Duta berperan dalam pengembangan masyarakat. Indikasinya tampak pada aktivitas pengembangan masyarakat, yang meliputi kelompok binaan, metode, materi melalui penyuluhan agama. Penyuluhan agama dilakukan dengan cara mentransformasikan pengetahuan agama dengan metode ceramah dan praktek ibadah, masyarakat diharapkan mengetahui dan menyadari akan pentingnya mengamalkan ajaran agama dalam kehidupan sehari-hari. Pola pengembangan masyarakat dilakukan dengan tahapan antara lain penjajakan, guna menciptakan kondisi agar masyarakat mau mengikuti penyuluhan dalam rangka pembentukan pribadi yang religius, memiliki kualitas rohaniah keagamaan, kecerdasan intelektual, makmur dan sejahtera dalam kehidupan sosial dan ekonomi. Fungsi kelembagaan dalam konteks pengembangan masyarakat, suatu kelembagaan yang didukung oleh sarana dan manajemen yang mencakup kepada pemihakan terhadap kepentingan rakyat.

Sebagai upaya memposisikan Dharma Duta dalam pengembangan masyarakat dapat dipahami dan realitas menunjukkan sebenarnya mereka memiliki peran penting dalam masyarakat. Dalam pelaksanaan tugas bimbingan dan penyuluhan sebenarnya merupakan tugas berat yang menuntut kompetensi dan keahlian dalam penguasaan materi atau pesan yang akan disampaikan kepada sasaran, metode penyampaian dan kemampuan komunikasi yang berkualitas, kemampuan membangun relasi dengan kelompok binaan, termasuk juga kualitas pengetahuan maupun kualitas moralnya. 
Jika dikaji sebenarnya ada sejumlah persyaratan yang harus dimiliki Dharma Duta, diantaranya Dharma Duta hendaknya memiliki pribadi yang menarik, serta berdedikasi tinggi dalam tugasnya. Di samping itu Dharma Duta harus mempunyai keyakinan bahwa kelompok binaan memiliki kemungkinan yang besar memperoleh kemampuan untuk berkembang sebaik-baiknya bila disediakan kondisi dan kesempatan yang mendukung itu. Dharma Duta juga hendaknya mempunyai kepedulian terhadap nilai-nilai kemanusiaan.

Dharma Duta seharusnya juga memiliki kemampuan untuk mengadakan komunikasi baik, bersifat terbuka, ulet dalam tugasnya, memiliki rasa cinta terhadap orang lain dan suka bekerja sama. Kemudian Dharma Duta hendaknya memiliki pribadi yang disukai oleh orang lain karena dapat diterima oleh masyarakat sekitar. Dharma Duta perlu peka terhadap kepentingan tersuluh, memiliki kecekatan berpikir dan cerdas. Sehingga mampu memahami kebutuhan masyarakat. Dharma Duta juga hendaknya memiliki kepribadian yang utuh, kematangan jiwa dan suka belajar khususnya ilmu pengetahuan yang berhubungan dengan tugasnya. Dharma Duta yang bertugas di bidang pembinaan agama atau penyuluh agama, sudah tentu penyuluh tersebut harus memiliki pengetahuan agama, berakhlak mulia dan aktif menjalankan ajaran agama secara benar dan konsisten.

Aktivitas penyuluhan agama dalam perkembangannya menjadi tugas dan fungsi pokok yang dimiliki oleh Lembaga Dharma Duta, bahkan pembinaan kelembagaan Lembaga Dharma Duta juga sudah menjadi kebijakan pembangunan agama yang dilakukan secara terprogram dan berkelanjutan oleh masyarakat maupun pemerintah, namun sejalan dengan dinamika sosial dan kultural sebagai dampak pembangunan maka dalam pembinaan kehidupan keagamaan dibutuhkan kajian tentang peran Dharma Duta secara luas dan mendalam.

Beban tugas Dharma Duta dalam masa pembangunan dewasa ini, dituntut agar mampu menyebarkan segala aspek pembangunan melalui pintu agama. Agar penyuluhan dapat berhasil, maka seorang Dharma Duta harus dapat memahami materi, menguasai betul metode ceramah dan teknik penyuluhan, dan mampu membangun relasi dengan kelompok binaan, sehingga diharapkan seorang Dharma Duta dapat mencapai tujuan Dharma Duta yaitu dapat mengubah masyarakat 
sasaran ke arah kehidupan yang lebih baik dan sejahtera lahir maupun batin. Wajar kiranya penyuluh agama diharapkan dapat berperan pula sebagai motivator pembangunan. Tugas Dharma Duta sangat penting karena pembangunan tidak semata-mata membangun manusia dari aspek lahiriah dan jasmani saja, melainkan juga membimbing dan membangun aspek rohaniah, mental spiritualnya, yang dilaksanakan secara simultan.

Peran Dharma Duta kini telah diwadahi oleh Lembaga Dharma Duta di bawah naungan Parisada Hindu Dharma Indonesia Pusat. Lembaga Dharma Duta memiliki peran penting dalam melakukan pembinaan kepada para Dharma Duta atau khususnya kepada penyuluh agama Hindu dalam mengoptimalkan upayaupaya dalam kegiatan pembinaan umat Hindu di Indonesia. Dengan terbinanya para penyuluh agama Hindu yang optimal maka akan mencetak penyuluh-penyuluh agama Hindu yang berkualitas dan memiliki kompetensi yang tinggi.

Dalam rangka mendukung pelaksanaan pembangunan nasional di bidang kehidupan beragama yang meliputi segala aspek kehidupan beragama, baik dalam peningkatan pelayanan kehidupan beragama, peningkatan pemahaman dan pengamalan agama, peningkatan kualitas pendidikan agama, maupun pembinaan lembaga sosial keagamaan dan lembaga tradisional keagamaan, maka Lembaga Dharma Duta diharapkan mampu mendukung dan ikut berperan serta dalam pembangunan nasional terutama dalam rangka pembinaan etika, moral dan spiritual umat beragama Hindu.

Dalam pembangunan di bidang mental dan spiritual, diharapkan kehidupan beragama dapat dijadikan sebagai pelopor etika bangsa, inspirator pembangunan dan motivator bagi terciptanya toleransi beragama. Untuk itu, pembangunan di bidang agama diharapkan di samping mampu meningkatkan penghayatan moral, kedalaman spiritual, dan etika keagamaan, juga dapat meningkatkan kualitas pemahaman, penghayatan, dan pengamalan ajaran agama, serta mengembangkan kehidupan keluarga ke arah keluarga sukinah serta memperkokoh kerukunan umat beragama.

Dalam mendukung tercapainya upaya-upaya tersebut, maka Lembaga Dharma Duta memiliki program, antara lain:

1. Ikut mengupayakan terwujudnya masyarakat agamis yang berperilaku luhur. 
2. Menghindarkan perilaku-prilaku radikal, ekstrim dan tidak toleran serta eksklusif dalam kehidupan beragama.

3. Membina masyarakat dalam meningkatkan pemahaman, penghayatan, dan pengamalan ajaran agama Hindu yang baik dan benar serta menghormati perbedaan keragaman kehidupan beragama melalui internalisasi ajaran agama yang inklusif.

Sehubungan dengan itu maka Lembaga Dharma Duta sangat diharapkan dapat melaksanakan tugas dan fungsinya dengan baik, dengan menyusun rencana kerja dan merealisasikannya dalam bentuk kegiatan-kegiatan yang bersifat konkret dan operasional, baik program jangka pendek maupun jangka panjang. Program jangka pendek ini diberikan prioritas untuk jangka waktu satu tahun, kemudian dijabarkan ke dalam bentuk langkah-langkah konkret sesuai dengan butir kegiatan yang telah ditetapkan dalam rencana operasional.

Rencana pembinaan yang akan dilakukan oleh Lembaga Dharma Duta kepada masyarakat yang menjadi wilayah binaannya, dilakukan secara konprehensif dan terpadu, artinya pembinaan yang dilaksanakan ada keterkaitan dengan stake-holders, dan memenuhi harapan masyarakat di bidang peningkatan etika, moral, dan spiritual. Karena demikian, kegiatan yang dilakukan oleh Lembaga Dharma Duta ini diharapkan dapat dilaksanakan secara terprogram dan terencana dengan baik.

Di dalam melaksanakan tugas pokok, Lembaga Dharma Duta akan melakukan kegiatan-kegiatan dengan beberapa cara, yaitu antara lain melalui pembinaan tatap muka langsung terjun ke masyarakat, orientasi, sosialisasi, workshop, loka karya, semi loka, seminar, melalui media cetak, pertunjukan, dan lain-lainnya.

Grand Design Hindu Dharma Indonesia yang mulai dikenalkan dan ditetapkan dalam Mahasabha X Parisada Hindu Dharma Indonesia pada 23-26 Oktober 2011 di Denpasar akan sangat baik jika didukung dengan kajian yang ilmiah, terutama dalam kaitan dengan peran Lembaga Dharma Duta yang juga sejalan dengan misi dari Grand Design Hindu Dharma Indonesia dalam upaya meningkatkan pemahaman umat dengan menyebarluaskan nilai-nilai ajaran Hindu serta menumbuhkembangkan wawasan, solidaritas, dan keharmonisan, sehingga 
perlu melakukan kajian bagaimana Lembaga Dharma Duta dan Tim Koordinasi dan Integrasi Grand Design Hindu Dharma Indonesia dapat bersinergi dengan sangat baik dalam menjalankan road-map grand design yang telah ditentukan.

\section{Rumusan Masalah}

Berdasarkan uraian latar belakang tersebut di atas, maka dapat diangkat rumusan masalah sebagai berikut : "Bagaimana peran Lembaga Dharma Duta dalam membangun sinergi dengan Tim Koordinasi dan Integrasi Grand Design Hindu Dharma Indonesia dalam meningkatkan kualitas Penyuluh Agama Hindu di Indonesia ?

\section{Tujuan Penelitian}

Berdasarkan latar belakang dan rumusan masalah yang diuraikan di atas, maka ditetapkan tujuan penelitian sebagai bagian penting dari setiap proses kegiatan. Adapun tujuan penelitian yang hendak dicapai dalam penelitian ini adalah sebagai berikut:

1. Untuk mengetahui peran Lembaga Dharma Duta dalam meningkatkan kualitas Penyuluh Agama Hindu di Indonesia;

2. Untuk mengetahui Peran Tim Koordinasi dan Integrasi Grand Design Hindu Dharma Indonesia dalam menyusun rencana dan strategi meningkatkan kualitas Penyuluh Agama Hindu di Indonesia;

3. Untuk mengetahui Sinergi peran Lembaga Dharma Duta dengan Tim Koordinasi dan Integrasi Grand Design Hindu Dharma Indonesia dalam meningkatkan kualitas Penyuluh Agama Hindu di Indonesia.

\section{Manfaat Penelitian}

Manfaat penelitian ini dibagi menjadi dua, yaitu manfaat teoritis dan manfaat praktis. Secara teoritis, hasil penelitian ini diharapkan dapat memberikan konsep operasional dan naskah akademik bagi akademisi, peneliti, praktisi, dan pengambil kebijakan di bidang pendidikan agama Hindu, serta sebagai referensi untuk pengembangan dan penelitian selanjutnya. Secara Praktis manfaat hasil penelitian ini diharapkan secara signifikan bermanfaat secara praktis bagi Lembaga Dharma Duta dan Tim Koordinasi dan Integrasi Grand Design Hindu Dharma Indonesia yang komponennya terdiri dari tujuh organisasi Hindu berskala nasional yaitu Parisada Hindu Dharma Indonesia (PHDI), Wanita Hindu Dharma Indonesia 
(WHDI), Perhimpunan Pemuda Hindu Indonesia (Peradah Indonesia), Kesatuan Mahasiswa Hindu Dharma Indonesia (KMHDI), Pinandita Sanggraha Nusantara (PSN), Prajaniti Hindu Indonesia (Prajaniti), dan Ikatan Cendekiawan Hindu Indonesia (ICHI) dalam upaya bersinergi meningkatkan kualitas penyuluh Hindu dan pembinaan umat Hindu di Indonesia.

\section{METODOLOGI PENELITIAN}

\section{Paradigma Penelitian}

Paradigma adalah ibarat sebuah jendela tempat orang mengamati dunia luar, tempat orang bertolak menjelajahi dunia dengan wawasannya (world-view). Namun secara umum, paradigma dapat diartikan sebagai seperangkat kepercayaan atau keyakinan dasar yang menuntun seseorang dalam bertindak dalam kehidupan sehari-hari. Pengertian ini sejalan dengan Guba yang dikonsepsikan oleh Thomas Kuhn sebagai seperangkat keyakinan mendasar yang memandu tindakan - tindakan kita, baik tindakan keseharian maupun dalam penyelidikan ilmiah. (Guba dalam Salim; 2001;33)

Paradigma Postpositivisme merupakan aliran yang ingin memperbaiki kelemahan-kelemahan positivisme yang hanya mengandalkan kemampuan pengamatan langsung terhadap objek yang diteliti. Secara otologis, aliran ini bersifat critical realism yang memandang sama bahwa realitas memang ada dalam kenyataan sesuai dengan hukum alam, tetapi suatu hal yang mustahil bila suatu realitas dapat dilihat secara benar oleh manusia (peneliti). Oleh karena itu, secara metodologis pendekatan eksperimental melalui observasi tidaklah cukup, tetapi harus menggunakan metode triangulation yaitu penggunaan bermacam-macam metode, sumber data, peneliti dan teori.

Secara epistemologis, hubungan antara pengamat atau peneliti dengan objek atau realitas yang diteliti tidaklah bisa dipisahkan, seperti yang diusulkan oleh aliran positivisme. Aliran ini menyatakan suatu hal yang tidak mungkin mencapai atau melihat kebenaran apabila pengamat berdiri dibelakang layar tanpa ikut terlibat dengan objek secara langsung. Oleh karena itu, dengan catatan bahwa pengamat harus bersifat senetral mungkin, sehingga tingkat subjektivitas dapat dikurangi secara minimal. 


\section{Pendekatan Penelitian}

Penelitian ini merupakan penelitian kualitatif. Berg (dalam Satori dan Komariah, 2010: 23) menyatakan bahwa "Qualitative Research (QR) thus refers to the meaning, conceps, definition, characteristics, simbols, and descriptions of things". Maksudnya adalah penelitian kualitatif mengacu pada suatu maksud atau arti, konsep-konsep, definisi, karakteristik, simbol-simbol, dan deskripsi dari berbagai hal. Bogdan dan Taylor (dalam Moleong, 2010: 4), menjelaskan metode kualitatif merupakan sebuah prosedur penelitian yang menghasilkan data deskriptif berupa kata-kata tertulis maupun lisan dari orangorang maupun perilaku yang dapat diamati. Sejalan dengan definisi tersebut, Kirk dan Miller (dalam Moleong, 2010: 4) mendefinisikan metode kualitatif sebagai suatu tradisi dalam ilmu pengetahuan yang bergantung pada pengamatan seseorang. Pengamatan tersebut berhubungan dengan orang-orang tersebut dalam bahasanya dan peristilahannya.

Berdasarkan penjelasan-penjelasan di atas, maka dapat disimpulkan bahwa penelitian kualitatif merupakan suatu prosedur penelitian yang menekankan pada kualitas atau mutu suatu penelitian yang mengacu pada teori, konsep, definisi, karakteristik, maupun simbol-simbol. Penelitian tersebut dilakukan berdasarkan pengamatan seseorang terhadap latar alamiah atau lingkungan sosial yang menghasilkan data deskriptif.

Data deskriptif merupakan data yang berupa kata-kata, gambar dan bukan angka-angka (Moleong, 2010: 11). Data deskriptif diperoleh dalam sebuah penelitian kualitatif yang hasilnya dideskripsikan berdasarkan pada tujuan penelitian. Data ini biasa ditemukan dalam struktur internal bahasa, yaitu struktur bunyi (fonologi), struktur kata (morfologi), struktur kalimat (sintaksis), struktur wacana dan struktur semantik (Chaer, 2007: 9).

\section{Metode Penelitian}

Penelitian ini menggunakan deskriptif kualitatif yang menekankan pada data yang dikumpulkan berupa kata-kata, gambar, dan bukan angkaangka. Hal ini disebabkan oleh adanya penerapan metode kualitatif. Selain itu, semua yang dikumpulkan berkemungkinan menjadi kunci terhadap apa yang sudah diteliti. 
Dengan demikian, laporan penelitian akan berisi kutipan-kutipan data untuk member gambaran penyajian laporan tersebut. Data tersebut mungkin berasal dari naskah wawancara, catatan lapangan, foto, videotape, dokumen pribadi, catatan atau memo, dan dokumen resmi lainnya. Pada penulisan laporan demikian, peneliti menganalisis data yang sangat kaya tersebut dan sejauh mungkin dalam bentuk aslinya. Hal itu hendaknya dilakukan seperti orang merajut sehingga setiap bagian ditelaah satu demi satu. Pertanyaan dengan kata "mengapa", alasan apa, dan bagaimana terjadinya akan senantiasa dimanfaatkan oleh peneliti. Dengan demikian, peneliti tidak akan memandang bahwa sesuatu itu sudah memang demikian keadaannya.(Moleong:2007;6)

\section{Jenis dan Sumber Data}

Data merupakan sumber informasi yang didapatkan oleh peneliti melalui penelitian yang dilakukan. Data yang diperoleh nantinya akan diolah sehingga menjadi informasi baru yang dapat dimanfaatkan oleh pembacanya. Dalam penelitian ini, data diperoleh melalui dua sumber yaitu data primer dan data sekunder. Berikut adalah penjabaran sumber data yang digunakan peneliti dalam penelitian ini:

a. Data primer

Data primer yaitu data yang diperoleh secara langsung dari informan. Dalam penulisan ini, data primer diperoleh melalui hasil wawancara dengan informan. Penetapan informan dengan menggunakan purposive sampling.

b. Data sekunder

Data sekunder yaitu data yang diperoleh penulis untuk mendukung data primer.

\section{Metode Pengumpulan Data}

Metode secara umum diartikan sebagai proses, cara, atau prosedur yang digunakan untuk memecahkan suatu masalah. Metode yang digunakan untuk mengumpulkan data dalam penelitian ini adalah sebagai berikut:

\section{a. Studi Pustaka}

Studi pustaka merupakan langkah awal dalam metode pengumpulan data. Studi pustaka merupakan metode pengumpulan data yang diarahkan kepada pencarian data dan informasi melalui dokumen-dokumen, baik 
dokumen tertulis, foto-foto, gambar, maupun dokumen elektronik yang dapat mendukung dalam proses penulisan."Hasil penelitian juga akan semakin kredibel bila didukung foto-foto atau karya tulis akademik dan seni yang telah ada." (Sugiyono,2005:83). Studi pustaka merupakan landasan utama sehingga dapat dikatakan bahwa studi pustaka dapat memengaruhi kredibilitas hasil penelitian yang dilakukan.

\section{b. Observasi}

Observasi merupakan langkah kedua dalam melakukan pengumpulan data setelah peneliti melakukan studi pustaka. Observasi merupakan teknik pengumpulan data dengan cara melakukan pengamatan tentang keadaan yang ada di lapangan. Dengan melakukan observasi, peneliti menjadi lebih memahami tentang subyek dan obyek yang sedang diteliti.

\section{c. Wawancara}

Wawancara merupakan langkah yang diambil selanjutnya setelah observasi dilakukan. Wawancara atau interview merupakan teknik pengumpulan data dengan cara bertatap muka secara langsung antara pewawancara dengan informan. Wawancara dilakukan jika data yang diperoleh melalui observasi kurang mendalam. Hal tersebut sesuai dengan yang dikemukakan (Sugiyono,2005:72) bahwa "wawancara digunakan sebagai teknik pengumpulan data bila peneliti ingin mengetahui hal-hal dari informan yang lebih mendalam."

Dalam penelitian ini, wawancara dilakukan dengan 10 informan yang sangat berkaitan erat dengan masalah penelitian yang diteliti serta terlibat langsung dalam aktivitas-aktivitas sosialisasi yang dilakukan oleh Lembaga Dharma Duta serta Grand Design Hindu Dharma Indonesia, yang tentu saja memiliki latar belakang yang berbeda.

\section{Teknik Pengumpulan Data}

Langkah yang selanjutnya dilakukan oleh peneliti setelah menentukan metode pengumpulan data adalah menentukan teknik pengumpulan data yang akan dipakai. "Teknik pengumpulan data merupakan langkah yang paling strategis dalam penelitian, karena tujuan utama dari penelitian adalah 
mendapatkan data". (Sugiyono,2005:62). Teknik pengumpulan data sangat diperlukan dalam suatu penelitian karena hal tersebut digunakan peneliti untuk mendapatkan data yang akan diolah sehingga bisa ditarik kesimpulan. Terdapat bermacam teknik pengumpulan data yang biasa dipakai dalam melakukan penelitian. Berikut adalah teknik pengumpuan data yang digunakan penulis dalam penelitian ini:

\section{a. Studi Pustaka}

Studi pustaka salah satunya menggunakan teknik catat. Teknik catat merupakan teknik pengumpulan data dengan cara menggunakan bukubuku, literatur ataupun bahan pustaka, kemudian mencatat atau mengutip pendapat para ahli yang ada di dalam buku tersebut untuk memperkuat landasan teori dalam penelitian. Teknik catat ini menggunakan buku-buku, literatur, dan bahan pustaka yang relevan dengan penelitian yang dilakukan, biasanya dapat ditemukan di perpustakaan maupun di tempat penulis melakukan penelitian.

\section{b. Observasi Partisipatif}

Peneliti menggunakan teknik observasi partisipatif, yaitu observasi dimana "peneliti terlibat dengan kegiatan sehari-hari orang yang sedang diamati atau yang digunakan sebagai sumber data penelitian." (Sugiyono, 2005:64).

Dengan observasi di lapangan peneliti akan lebih mampu memahami konteks data dalam keseluruhan situasi sosial, jadi akan dapat diperoleh pandangan yang holistik atau menyeluruh."(Sugiyono, 2005: 67).

\section{c. Wawancara Terstruktur}

Penulis dalam penelitian ini menggunakan teknik wawancara terstruktur yaitu wawancara di mana penulis menggunakan daftar pertanyaannya yang telah disusun sebelumnya. Penulis menggunakan wawancara terstruktur agar pertanyaan lebih terfokus, sehingga data yang diperoleh tidak akan melenceng dari pokok permasalahan. 


\section{Teknik Analisis Data}

Akhirnya perlu dikemukakan bahwa analisis data itu dilakukan dalam suatu proses. Proses berarti pelaksanaannya sudah mulai dilakukan sejak pengumpulan data dilakukan dan dikerjakan secara intensif, yaitu sesudah meninggalkan lapangan. Dalam hal ini dianjurkan agar analisis data dan penafsirannya secepatnya dilakukan oleh penulis, jangan menunggu sampai data itu menjadi dingin bahkan membeku atau sampai kadaluwarsa. Pekerjaan menganalisis data memerlukan pemusatan perhatian dan pengerahan tenaga fisik dan pikiran peneliti. Selain menganalisis data, peneliti juga perlu dan masih perlu mendalami kepustakaan guna mengonfirmasikan teori atau untuk menjustifikasikan adanya teori baru yang barangkali ditemukan.

Analisis data menurut Patton 1980 ( dalam Moleong;2004;103-104), adalah "proses mengatur urutan data, mengorganisasikannya ke dalam suatu pola, kategori, dan satuan uraian dasar. Ia membedakannya dengan penafsiran, yaitu memberikan arti yang signifikan terhadap analisis, menjelaskan pola uraian, dan mencari hubungan diantara dimensi - dimensi uraian ".

Sedangkan Bogdan dan Taylor 1975 ( dalam Moleong;2004;103-104) mendefinisikan analisis data sebagai Proses yang merinci usaha secara formal untuk menemukan tema dan merumuskan hipotesis (ide) seperti yang disarankan oleh data dan sebagai usaha untuk memberikan bantuan pada tema dan hipotesis itu. Jika dikaji, pada dasarnya definisi pertama lebih menitikberatkan pengorganisasian data sedangkan yang kedua lebih menekankan maksud dan tujuan analisis data. Dengan demikian definisi tersebut dapat disintesiskan menjadi : Analisis data adalah proses mengorganisasikan dan mengurutkan data ke dalam pola, kategori, dan satuan uraian dasar sehingga dapat ditemukan tema dan dapat dirumuskan hipotesis kerja seperti yang disarankan oleh data.

Berdasarkan rumusan tersebut di atas dapatlah dinarik garis bawah analisis data bermaksud pertama - tama mengorganisasikan data. Data yang terkumpul banyak sekali dan terdiri dari catatan lapangan dan komentar peneliti, gambar, foto, dokumen berupa laporan, biografi, artikel dan sebagainya. Pekerjaan analisis data dalam hal ini ialah mengatur, mengurutkan, 
mengelompokkan, memberikan kode, dan mengategorikannya. Pengorganisasian dan pengelolaan data tersebut bertujuan menemukan tema dan hipotesis kerja yang akhirnya diangkat menjadi teori substantif.

Uraian diatas memberikan gambaran tentang betapa pentingnya kedudukan analisis data ini dilihat dari segi tujuan penelitian. Prinsip pokok penelitian kualitatif adalah menemukan teori dari data. Namun banyak juga ilmuwan yang memanfaatkannya untuk menguji atau memverifikasi teori yang sedang berlaku. Penemuan teori baru atau verifikasi teori baru akan tampak sewaktu analisis data ini mulai dilakukan. Walaupun kedudukannya penting, dengan sendirinya tahap analisis data ini hanya merupakan satu bagian yang tak terpisahkan dari tahap - tahap lainnya.

Menurut Miles dan Hubermas ; "Analisis kualitatif tetap menggunakan kata-kata yang biasanya disusun ke dalam teks yang diperluas." ( 1992 :15-16). Berdasarkan hal itu, maka analisis dalam penelitian ini dilakukan melalui tiga alur kegiatan yaitu :

a. Reduksi Data

Reduksi data merupakan proses pemilihan, pemusatan perhatian pada penyederhanaan, pengabstrakan dan transformasi data "kasar" yang muncul dari catatan-catatan tertulis di lapangan. Reduksi data ini berlangsung terusmenerus selama proses penelitian kualitatif ini berlangsung. Selama pengumpulan data, dilakukan pula tahap reduksi selanjutnya, membuat ringkasan, mengkode, menelusuri tema, membuat gugus, partisi dan menulis mereduksi data dan bahkan terus dilakukan sesudah penelitian lapangan, sampai laporan akhir tersusun, yang menurut Miles dan Hubermas ( 1992 :14), mengatakan bahwa reduksi data merupakan bagian dari analisis, pilihan peneliti tentang bagian mana yang di kode, mana yang dibuang, pola mana yang meringkas sejumlah bagian yang tersebar, cerita apa yang sedang berkembang, semuanya adalah pilihan analitis. Reduksi merupakan suatu bentuk analisis yang menajamkan, menggolongkan, mengarahkan, membuang yang tidak perlu dan mengorganisasi data dengan cara sedemikian rupa sehingga kesimpulan-kesimpulan finalnya dapat ditarik dan diverifikasi. 


\section{b. Penyajian Data}

Menurut Miles dan Hubermas (1992 : 16) :" Penyajian yang paling sering digunakan dalam data kualitatif pada masa lalu adalah teks naratif, “ Berdasarkan hal itu, penyajian data dalam penelitian ini dilakukan dengan berbagai jenis jaringan, tabel dan bagan yang dirancang sedemikian rupa guna menyajikan informasi yang tersusun dalam bentuk yang padu dan mudah diraih. Seperti yang dinyatakan oleh Miles dan Hubermas (1992; 18): “ dengan cara itu peneliti dapat melihat apa yang sedang terjadi dan menentukan apakah menarik kesimpulan secara benar ataukah terus melangkah melakukan analisis sesuai saran yang dikiaskan oleh penyajian sebagai sesuatu yang mungkin berguna”.

\section{c. Penarikan kesimpulan/Verifikasi}

Menurut Miles dan Hubermas (1992 :19) :"penarikan kesimpulan hanyalah sebagian dari suatu kegiatan konfigurasi yang utuh. Kesimpulan juga diverifikasi selama penelitian. Verifikasi mungkin sesingkat pikiran penganalisis selama ia menulis, tinjauan ulang pada catatan lapangan, tukar pikiran diantara teman sejawat untuk mengembangkan "kesepakatan intersubjektif". Singkatnya makna-makna yang muncul dari data harus diuji kebenarannya, kekokohannya, dan kecocokannya, yakni validitasnya.

\section{HASIL PENELITIAN}

Penelitian yang telah dihasilkan melalui metode dan pendekatan kualitatif. Dalam bab ini pula akan menekankan pada hasil penelitian dan pembahasan yang berkaitan dengan Pemahaman Tentang Lembaga Dharma Duta dan Grand Design Hindu Dharma Indonesia, Sinergisitas Lembaga Dharma Duta dengan Team Koordinasi dan Integrasi Grand Design Hindu Dharma Indonesia, serta Peran Lembaga Dharma Duta dalam Peningkatan Kualitas Penyuluh Agama Hindu di Indonesia. Hasil penelitian diolah dengan menggunakan pendekatan kualitatif dengan menekankan pada subjektifitas data dilapangan namun juga mampu menghasilkan data secara objektif, serta selanjutnya dianalisis berdasarkan teknik analisis data dalam pendekatan kualitatif.

Berkaitan dengan peningkatan kualitas penyuluh Agama Hindu di Indonesia, tentu tidak bisa dilepaskan dari peran lembaga atau institusi serta 
organisasi masyarakat Hindu Indonesia yang memiliki peranan yang sangat besar dalam proses peningkatan kualitas penyuluh Agama Hindu tersebut. Diantaranya ada lembaga Dharma Duta yang berada dibawah naungan Parisadha Hindu Dharma Indonesia Pusat. Peran penting diemban oleh lembaga Dharma Duta dalam melakukan pembinaan kepada para Dharma Duta atau khususnya para penyuluh Agama Hindu seluruh Indonesia yanmg tujuannya tentu saja untuk mengoptimalkan kualitas-kualitas yang dimiliki oleh para penyuluh Agama Hindu tersebut.

Berkaitan dengan sosialisasi serta eksistensi Lembaga Dharma Duta di tengah-tengah masyarakat Hindu masih menjadi kekhawatiran bersama, dimana banyak masyarakat Hindu yang masih belum mengetahui secara detail keberadaan dari Lembaga Dharma Duta ini serta manfaatnya secara real di masyarakat. Sebagian besar dari mereka hanya sekedar mendapatkan informasi saja yang berkaitan dengan Lembaga Dharma Duta. Informasi tersebut ada yang berasal dari teman, akses internet, kegiatan di pura dan lain-lain.

Masyarakat Hindu masih memahami Lembaga Dharma Duta secara lembaga yang masih belum tersentuh oleh kebutuhan masyarakat Hindu di Indonesia, dimana pemaparan dari hasil penelitian yang dilakukan di lapangan yang menyatakan bahwa. Lembaga Dharma Duta adalah lembaga penyiaran informasi serta lembaga penyebaran falsafah Hindu yang dinaungi oleh Parisada Hindu Dharma Indonesia Pusat, sehingga dapat dikatakan bahwa, pemahaman masyarakat Hindu tersebut masih bersifat informatif belum pada esensi yang kongkret tentang kerja dari Lembaga Dharma Duta.

Pada pernyataan diatas tentu dapat diketahui bahwa pengetahuan masyarakat Hindu terkait dengan Lembaga Dharma Duta masih pada paparan normatif definitif saja, sehingga masih dibutuhkan upaya yang lebih keras lagi agar masyarakat Hindu mampu memiliki pemahaman tentang Lembaga Dharma Duta sudah sampai pada tataran aplikatif.

Berkaitan dengan peningkatan kualitas para penyuluh Agama Hindu di Indonesia, Lembaga Dharma Duta juga harus mampu membangun sinergisitas dengan lembaga atau organisasi Hindu lainnya. Seperti kita ketahui yaitu Grand 
Design Hindu Dharma Indonesia (GDHDI) yang juga memiliki peranan penting dalam peningkatan kualitas-kualitas para penyuluh Agama Hindu di Indonesia.

Parisada Hindu Dharma Indonesia sebagai majelis tertinggi agama Hindu bersama organisasi kemasyarakatan Hindu serta seluruh pemangku kepentingan (stake holders) di Indonesia memiliki tanggung jawab utama dalam menentukan arah dan bentuk-bentuk kontribusi umat Hindu dalam kehidupan bangsa Indonesia ke depan. Oleh karenanya, dalam forum Pesamuhan Agung Parisada Tahun 2011, Panitia Pesamuhan Agung mengambil inisiatif dan mengusulkan rancangan "Grand Design Hindu Nusantara" yang kemudian disepakati dengan nama "Grand Design Hindu Dharma Indonesia (GDHDI)" sebagai desain utama strategi pembinaan dan pengembangan Hindu di Indonesia.

Rancangan "Grand Design Hindu Dharma Indonesia (GDHDI)" ini disahkan oleh Parisada Hindu Dharma Indonesia sebagai majelis tertinggi agama Hindu Indonesia pada Mahasabha X Parisada di Denpasar, tahun 2011. "Grand Design Hindu Dharma Indonesia" ini dijadikan sebagai acuan arah (visi) dan peta perjalanan umat Hindu Indonesia dalam kurun waktu 50 tahun yang akan datang. Namun hasil observasi dilapangan ditemukan bahwa, masih banyak masyarakat Hindu yang belum mengetahui secara real implementasi program yang dilakukan oleh GDHI yang diharapkan akan mampu menjawab segala kebutuhan umat Hindu di Indonesia. Berkaitan dengan pemahaman masyarakat Hindu terkait dengan GDHDI cukup beragam.

Dengan demikian, mendesain masa depan Hindu di Indonesia pada dasarnya adalah proses yang diskenariokan agar bertahan hidup dan menuju pertumbuhan umat Hindu di Indonesia, baik dalam kuantitas dan kualitas. Agar bertahan hidup maka harus bertumbuh ( row). Menurut teori, cara bertumbuh ada dua, yang pertama adalah grow by accident dan yang kedua adalah grow by design. Grow by accident pada hakikatnya adalah "menuju ke lembah kematian". Sedangkan grow by design berarti dengan sengaja mendesain diri sendiri dengan cara menentukan visi, menetapkan strategi, dan membuat rencana implementasinya. Dalam manajemen strategik, ada empat tahapan utama yang umum diterapkan yaitu Situation Analysis, Strategy Formulation, Strategy Implementation, dan Evaluation \& Control. 
Grand Design Hindu Dharma Indonesia adalah rumusan yang merupakan rencana induk (master plan) pertumbuhan Hindu di Indonesia sebagai hasil dari tahap pertama dan kedua dalam manajemen strategik, yaitu tahap Situation Analysis dan Strategy Formulation. Agar rencana induk ini dapat diimplementasikan maka perlu disosialisasikan kepada seluruh pemangku kepentingan (stake holders) di Indonesia dan juga perlu disiapkan agen-agen perubahan (change agents) yang menjalankannya. Dalam konteks manajemen strategik, dua tahap berikutnya harus dijalankan secara berkesinambungan, yaitu tahap Strategy Implementation dan tahap Evaluation \& Control.

Selain berbicara pada paparan strategis yang menjadi unggulan program yang dimiliki oleh GDHDI, namun berkaitan dengan pemahaman tentang Grand Design Hindu Dharma Indonesia, sehingga, berangkat dari hasil penelitian tersebut, penting sekali para lembaga Hindu serta organisasi-organisasi Hindu di Indonesia untuk lebih berupaya keras untuk meningkatkan pemahaman masyarakat Hindu terkait dengan implemantasi program-program kerja yang dimiliki oleh para lembaga serta organisasi-organisasi Hindu tersebut. Hal itu berkaitan dengan eksistensi lembaga dan organisasi untuk mampu menjawab segala kebutuhan umat Hindu di Indonesia dalam hal ini adalah peningkatan kualitas para penyuluh Agama Hindu di seluruh Indonesia. Sinergisitas adalah hal penting yang harus dilakukan oleh sesame lembaga Hindu serta organisasi Hindu di Indonesia. Karena hal tersebut berkaitan dengan koordinasi kerja lembaga Hindu dan Organisasi Hindu untuk bersama-sama membangun, membesarkan serta menjawab segala kebutuhan masyarakat Hindu di Indonesia baik berkaitan dengan informasi teknis, regulasi serta ajaran-ajaran spriritual tentang Dharma.

Berkaitan dengan sinergisitas yang dilakukan oleh Lembaga Dharma Duta dan team Koordinasi dan Integrasi Grand Design Hindu Dharma Indonesia (GDHDI) masih menjadi keingintahuan yang sangat besar oleh masyarakat Hindu di Indonesia, dimana masih minimnya pengetahuan dan informasi terkait sinergisitas tersebut serta dampak secara real terkait sinergisitas yang telah dilakukan.

Para Dharma Duta atau penyuluh Agama Hindu memiliki peran yang sangat penting bukan hanya sebagai penyuluh yang menyebarkan ajaran-ajaran dharma 
dalam Agama Hindu tetapi juga harus mampu memiliki orientasi pada pembangunan di bidang mental dan spiritual, terfokus pada kehidupan beragama sehingga dapat dijadikan sebagai pelopor etika bangsa, inspirator pembangunan dan motivator bagi terciptanya toleransi beragama, serta inspirasi yang positif untuk memahami ajaran-ajaran dharma dalam Agama Hindu. Sehingga dengan demikian pembangunan di bidang agama Hindu diharapkan akan mampu meningkatkan penghayatan moral, kedalaman spiritual, dan etika keagamaan, juga dapat meningkatkan kualitas pemahaman, penghayatan, dan pengamalan ajaran agama, serta mengembangkan kehidupan keluarga ke arah keluarga sukinah serta memperkokoh kerukunan umat beragama.

Peran Penyuluh Agama Hindu yang terbina dalam Lembaga Dharma Duta tidaklah mudah, karena peran penting yang harus dimiliki adalah kapasitas untuk mendukung pelaksanaan pembangunan nasional di bidang kehidupan beragama yang meliputi segala aspek kehidupan beragama, baik dalam peningkatan pelayanan kehidupan beragama, peningkatan pemahaman dan pengamalan agama, peningkatan kualitas pendidikan agama, maupun pembinaan lembaga sosial keagamaan dan lembaga tradisional keagamaan, maka Lembaga Dharma Duta diharapkan mampu mendukung dan ikut berperan serta dalam pembangunan nasional terutama dalam rangka pembinaan etika, moral dan spiritual umat beragama Hindu.

Berkaitan dengan fungsi dan peranan yang dimiliki oleh Lembaga Dharma Duta, maka harus ada pencapaian-pencapaian tertentu yang dimiliki oleh lembaga Dharma Duta dalam merealisasikan program kerjanya. Seperti diketahui bahwa, Lembaga Dharma Duta memiliki program, antara lain:

a. Ikut mengupayakan terwujudnya masyarakat agamis yang berperilaku luhur.

b. Menghindarkan perilaku-prilaku radikal, ekstrim dan tidak toleran serta eksklusif dalam kehidupan beragama.

c. Membina masyarakat dalam meningkatkan pemahaman, penghayatan, dan pengamalan ajaran agama Hindu yang baik dan benar serta menghormati perbedaan keragaman kehidupan beragama melalui internalisasi ajaran agama yang inklusif. 
Namun dalam perkembangannya, pada hasil penelitian ini, banyak perkembangan program kerja yang berkaitan dengan peran Lembaga Dharma Duta secara real masih menjadi pengharapan besar masyarakat Hindu Indonesia.

Banyak solusi serta pendapat yang ditawarkan oleh masyarakat Hindu berkaitan dengan peningkatan peran Lembaga Dharma Duta dalam meningkatkan kualitas-kualitas yang dimiliki oleh para penyuluh Agama Hindu yang ada di Indonesia. Bukan hanya pada pembinaan saja, namun juga lebih pada strategi yang tepat untuk memaksimalkan kualitas yang dimiliki sehingga mampu menjawab segala kebutuhan masyarakat Hindu di Indonesia. Harapan kepada Lembaga Dharma Duta kedepannya mampu lebih berperan besar terhadap peningkatan kualitas dari para penyuluh Agama Hindu di Indonesia melalui program-program kerja yang memiliki visi yang matang kedepannya serta koordinasi dan strategi yang tepat untuk mengimplementasikan setiap program kerja tersebut

Analisis dari hasil penelitian yang telah dilakukan bahwa, Lembaga Dharma Duta memiliki peranan yang sangat penting dalam peningkatan kualitas penyuluh Agama Hindu atau para Dharma Duta. Namun kerja keras masih harus dilakukan lebih giat lagi berkaitan dengan pengelolaan SDM penyuluh Agama Hindu yang masih harus dikoordinir secara serius, anggaran operasional berkaitan dengan pemberdayaan penyuluh Agama Hindu, pembinaan dan pembekalan terkait pendidikan akademis serta akses informasi yang lebih mudah terkait dengan pengetahuan-pengetahuan Agama Hindu, sosialisasi dan publikasi terkait aktivitas dan kegiatan para penyuluh Agama Hindu masih memerlukan perhatian khusus saat ini.

Begitu pula dengan koordinasi yang diharapkan akan mampu membangun sinergisitas kerja yang baik antara Lembaga Dharma Duta dan Grand Design Hindu Dharma Indonesia terkait dengan peningkatan kualitas Penyuluh Agama Hindu Indonesia, yang tentu saja masih butuh sosialisasi yang intens terkait implementasi program kerja dari keduanya kepada masyarakat Hindu. Karena pada dasarnya yang menjadi perhatian adalah bagaimana peningkatan peran Lembaga Dharma Duta dalam meningkatkan kualitas yang dimiliki oleh para penyuluh Agama Hindu yang ada di Indonesia agar mampu sampai pada setiap aspek kehidupan masyarakat Hindu. Bukan hanya pada pembinaan saja, namun juga lebih pada strategi yang 
tepat untuk memaksimalkan kualitas yang dimiliki oleh para penyuluh Agama Hindu sehingga mampu menjawab segala kebutuhan masyarakat Hindu di Indonesia.

\section{SIMPULAN}

Berdasarkan pembahasan pada Bab-bab sebelumnya, maka dapat ditarik kesimpulan, diantaranya adalah :

1. Masih dibutuhkannya sosialisasi yang riil kepada masyarakat Hindu di Indonesia terkait dengan program kerja yang dimiliki oleh Lembaga Dharma Duta dan Grand Design Hindu Indonesia

2. Masih dibutuhkannya koordinasi yang kuat antara Lembaga Dharma Duta serta Grand Design Hindu Dharma Indonesia terkait dengan rencana dan implementasi kerja yang bertujuan untuk peningkatan kualitas penyuluh Agama Hindu di Indonesia.

3. Dibutuhkan keseriusan serta kefokusan yang tepat dari Lembaga Dharma Duta terkait dengan banyak aspek yang masih dibutuhkan dalam peningkatan kualitas Penyuluh Agama Hindu seperti pembinaan dan pengelolaan, anggaran, pendidikan akademis, dll.

4. Dibutuhkan program dan strategi kerja yang tepat yang harus dirancang bersama oleh Lembaga Dharma Duta dan Grand Design Hindu Dharma Indonesia untuk meningkatkan dan memaksimalkan kualitas yang dimiliki oleh penyuluh Agama Hindu di seluruh Indonesia.

\section{SARAN}

Berdasarkan uraian kesimpulan sebagaimana tersebut di atas, maka saran-saran yang dapat penulis kemukakan ditujukan kepada :

1. Pengurus Parisada Hindu Dharma Indonesia Pusat dan Daerah serta kepada Pengurus Lembaga Dharma Duta, hendaknya lebih mengintensifkan lagi program sosialisasi yang terkait dengan program kerja yang dimiliki baik oleh Lembaga Dharma Duta maupun Tim Grand Design Hindu Dharma Indonesia. Di samping itu diperlukan adanya koordinasi secara terintegrasi dan sinkronisasi yang kuat antara Pengurus Lembaga Dharma Duta dengan 
Tim Grand Design Hindu Dharma Indonesia terkait dengan rencana dan implementasi kerja dalam usaha peningkatan kualitas penyuluh Agama Hindu di Indonesia.

2. Pengurus Parisada Hindu Dharma Indonesia, terutama Parisada Provinsi agar sesegera mungkin membentuk Lembaga Dharma Duta sesuai dengan daerahnya masing-masing. Hal ini bertujuan untuk lebih memantapkan pelaksanaan tugas-tugas pembinaan sesuai dengan program-program kerja Lembaga Dharma Duta yang berkaitan dengan peningkatan kualitas Penyuluh Agama Hindu di Indonesia.

3. Para Pembina Umat Hindu, baik secara kelembagaan maupun secara perorangan hendaknya ikut pula berperan serta dalam rangka melakukan sosialisasi secara estapet mengenai program-program yang dimiliki oleh Lembaga Dharma Duta maupun Tim Grand Desain Hindu Dharma Indonesia. Hal ini bertujuan untuk mempercepat proses pemahaman Umat Hindu sampai ke akar rumput tentang keberadaan Lembaga Dharma Duta dan Grand Design Hindu Dharma Indonesia.

4. Direktur Jenderal Bimbingan Masyarakat Hindu dan semua jajarannya baik pusat maupun daerah, diharapkan dapat memprogramkan pembinaanpembinaan yang berkaitan dengan kegiatan-kegiatan Lembaga Dharma Duta kedalam bentuk anggaran untuk memperlancar pembinaan-pembinaan yang dilaksanakan oleh Lembaga Dharma Duta tersebut, baik Lembaga Dharma Duta Pusat maupun Lembaga Dharma Duta yang ada di daerah (bagi daerah yang telah terbentuk). 


\section{DAFTAR PUSTAKA}

Bungin, B. 2003. Analisis Data Penelitian Kualitatif. Jakarta. PT Rajagrafindo. Persada.

Creswell, Jhon W, 1998, Qualitative Inquiry and Research Design, Choosing Among Five Traditions, SAGE Publication.

Departemen Agama RI Proyek Pembinaan Lembaga Keagamaan, 1994/1995, Pola Pembinaan Lembaga Keagamaan Hindu, Jakarta.

Departemen Pendidikan dan Kebudayaan, Kamus Besar Bahasa Indonesia, 1995, Balai Pustaka, Jakarta.

Djajasudarma, T. Fatimah. 2006. Metode Linguistik Ancangan Metode Penelitian dan Kajian. Bandung. Reflika Aditama.

Hadari Nawawi dan Martini Nawawi. 1995. Instrumen Penelitian Bidang Sosial. Yogyakarta. Gadjah Mada University Press.

Kadjeng, I Nyoman dkk. 1997. Sarasamuscaya dengan teks Bahasa Sansekerta dan Jawa Kuna. Penerbit Paramita Surabaya.

Kriyantono, Rachmat, Ph.D, 2006, Teknik Praktis Riset Komunikasi, Kencana Prenada Media Group, Jakarta

Juni Pranoto dan Wahyu Suprapti, 2006, Membangun Kerjasama Tim (Team Building), Lembaga Administrasi Negara, Lembaga Administrasi Negara,

Moleong, Lexy. 2002, Metodologi Penelitian Kualitatif, Bandung: PT. Remaja Rosdakarya.

Mustafa, Hasan, 2000. Teknik Sampling, Bandung, Alfabeta.

Parisada Hindu Dharma Indonesia, 2005, Kompilasi Dokumen Literer 45 tahun Parisada, Jakarta. , 2010, Hasil-hasil Pesamuhan Agung Parisada Hindu Dharma Tahun 2010, Parisada Hindu Dharma Indonesia, Jakarta.

,2013, Swastikarana Pedoman Ajaran Umat Hindu, Jakarta.

Poerwandari, K. 1998. Pendekatan Kualitatif dalam Penelitian Psikologi. Jakarta. LPSP3 Universitas Indonesia.

Prabowo. 1996. Memahami Penelitian Kuantitatif. Yogyakarta. Andi Offset.

Pusat Kerukunan Umat Beragama Departemen Agama RI, 2007, Manajemen Konflik Umat Beragama, Jakarta.

Riduwan, 2006, Belajar Mudah Penelitian, Alfabeta, Bandung.

Salim, Agus, 2001. Teori dan Paradigma Penelitian Sosial, Tiara Wacana Yogya, Yogyakarta

Sargede, 2005, Kebangkitan Hindu, Paramita, Surabaya.

Suasthi dan Suastawa, Psikologi Agama, 2008, Widya Dharma, Denpasar.

Sugiyono. 2002. Metodologi Penelitian Administrasi. Yogyakarta. CV Alfabeta. 
2008, Metode Penelitian Pendidikan (Pendekatan Kuantitatif, Kualitatif dan $R \& D$ ), Alfabeta, Bandung.

Tim Penyusun, Pedoman Tenaga Pembina, 2007, Mitra Abadi Press, Jakarta.

, Pedoman dan Petunjuk Pelaksanaan Kegiatan Pejabat Fungsional Penyuluh Agama Hindu, 2004, Paramita, Surabaya. , Petunjuk Teknis Dharma Wacana, 2007, Paramita, Surabaya.

Tim Penyusun, 2013, Grand Design Hindu Dharma Indonesia, Parisada Hindu Dharma Indonesia, Jakarta.

Yin, Robert K. 2003. Studi Kasus Desain dan Metode. Jakarta. Raja Grafindo Persada. 